Article

\title{
Dynamic Chloroplast Genome Rearrangement and DNA Barcoding for Three Apiaceae Species Known as the Medicinal Herb "Bang-Poong"
}

\author{
Hyun Oh Lee ${ }^{1,2,+}$, Ho Jun Joh ${ }^{1,+}$, Kyunghee Kim ${ }^{1}$, Sang-Choon Lee ${ }^{2}$, Nam-Hoon Kim ${ }^{1,2}$, \\ Jee Young Park ${ }^{1}$, Hyun-Seung Park ${ }^{1}$, Mi-So Park ${ }^{2}$, Soonok Kim ${ }^{3}$, Myounghai Kwak ${ }^{4}$, \\ Kyu-yeob Kim ${ }^{5}$, Woo Kyu Lee ${ }^{6}$ and Tae-Jin Yang ${ }^{1, *}$ \\ 1 Department of Plant Science, Plant Genomics and Breeding Institute, and Research Institute for Agriculture \\ and Life Sciences, College of Agriculture and Life Sciences, Seoul National University, Seoul 08826, Korea; \\ dlgusdh88@snu.ac.kr (H.O.L.); zerosight@snu.ac.kr (H.J.J.); kkhpyh@hanmail.net (K.K.); \\ nhkim@phyzen.com (N.-H.K.); jypark74@snu.ac.kr (J.Y.P.); fgenesis@snu.ac.kr (H.-S.P.) \\ 2 Phyzen Genomics Institute, 605, Baekgoong Plaza1, Seongnam 13558, Korea; \\ sclee0923@hanmail.com (S.-C.L.); iamparkmiso@naver.com (M.-S.P.) \\ 3 Genetic Resources Assessment Division, National Institute of Biological Resources, Incheon 404-170, Korea; \\ sokim90@korea.kr \\ 4 Plant Resources Division, National Institute of Biological Resources, Incheon 404-170, Korea; \\ mhkwak1@korea.kr \\ 5 Herbal Medicine Research Division, Ministry of Food and Drug Safety, Cheongju 28159, Korea; \\ yeop007@korea.kr \\ 6 Criminal Investigation Office, Ministry of Food and Drug Safety, Cheongju 28159, Korea; \\ leewk1977@korea.kr \\ * Correspondence: tjyang@snu.ac.kr; Tel.: +82-2-880-4547 \\ + These authors contributed equally to this work.
}

Received: 7 March 2019; Accepted: 30 April 2019; Published: 4 May 2019

\begin{abstract}
Three Apiaceae species Ledebouriella seseloides, Peucedanum japonicum, and Glehnia littoralis are used as Asian herbal medicines, with the confusingly similar common name "Bang-poong". We characterized the complete chloroplast (cp) genomes and $45 \mathrm{~S}$ nuclear ribosomal DNA (45S nrDNA) sequences of two accessions for each species. The complete cp genomes of $G$. littoralis, L. seseloides, and P. japonicum were 147,467, 147,830, and 164,633 bp, respectively. Compared to the other species, the $P$. japonicum cp genome had a huge inverted repeat expansion and a segmental inversion. The $45 \mathrm{~S}$ nrDNA cistron sequences of the three species were almost identical in size and structure. Despite the structural variation in the P. japonicum cp genome, phylogenetic analysis revealed that G. littoralis diverged 5-6 million years ago (Mya), while P. japonicum diverged from L. seseloides only 2-3 Mya. Abundant copy number variations including tandem repeats, insertion/deletions, and single nucleotide polymorphisms, were found at the interspecies level. Intraspecies-level polymorphism was also found for L. seseloides and G. littoralis. We developed nine PCR barcode markers to authenticate all three species. This study characterizes the genomic differences between L. seseloides, P. japonicum, and G. littoralis; provides a method of species identification; and sheds light on the evolutionary history of these three species.
\end{abstract}

Keywords: Ledebouriella seseloides; Peucedanum japonicum; Glehnia littoralis; chloroplast genome; inverted repeat (IR) expansion; phylogenetic analysis; divergence time estimation 


\section{Introduction}

Apiaceae (Umbelliferae) is one of the largest families of flowering plants. It comprises approximately 450 genera and 3700 species, which are widely distributed across the temperate zone $[1,2]$. This family is characterized by a simple or complex compound inflorescence, called an umbel, which resembles the ribs of an umbrella. The family includes well-known plant species used for cooking, such as carrot (Daucus carota), celery (Apium graveolens), and parsley (Petroselinum crispum), as well as many others used in traditional medicine in Eastern Asia [3].

The Apiaceae species Ledebouriella seseloides (Hoffm.) H. Wolff is known as Bang-poong in Korea, Fang-feng in China, and Bo-fu in Japan, all rendered with the same Chinese characters [3-5]. The dried roots and rhizomes of $L$. seseloides are used in traditional medicine to treat headaches, vertigo, and generalized aching [6]. Two other Apiaceae species, Peucedanum japonicum Thunb. $(n=11)$ [7] and Glehnia littoralis F. Schmidt ex Miq. $(n=11)$ [8], have similar common names, Sik-Bang-Poong and Hae-Bang-Poong, respectively, and are sold in traditional Korean medicine markets as alternatives to L. seseloides [5]. Thus, it is necessary to clearly classify each species and to develop a DNA barcoding tool to authenticate each species.

Plant genetic barcode markers are often based on chloroplast (cp) genomes and 45S nuclear ribosomal DNA (nrDNA) because these sequences are well conserved across plant species and show clear interspecies polymorphism with rare intraspecies polymorphism [9]. The cp genome is a circular molecule of 120-217 kb, which generally comprises a large single-copy (LSC) region, a small single-copy (SSC) region, and two inverted repeat (IR) regions $[9,10]$. The $45 \mathrm{~S}$ nrDNA cistron unit encodes $5.8 \mathrm{~S}$, 18S, and 26S rRNAs, separated by internal transcribed spacer 1 (ITS1) and ITS2 [9]. To classify plants and develop molecular markers, studies have analyzed regions including intergenic spacers (IGSs) or coding sequences in the cp genome, and ITS sequences in $45 \mathrm{~S}$ nrDNA $[9,11,12]$. Notably, both cp genome DNA and 45S nrDNA are highly abundant in plant tissue extracts because there are hundreds of copies of the cp genome in cytoplasmic organelles and thousands of tandem array copies of $45 \mathrm{~S}$ nrDNA in cell nuclei [9].

In this study, we characterized the complete cp genomes and $45 \mathrm{~S}$ nrDNA cistron units of three medicinal plants, L. seseloides, P. japonicum, and G. littoralis, using a low-coverage whole-genome sequencing (WGS) approach (dnaLCW) for highly efficient, simultaneous de novo assembly of cp and $45 \mathrm{~S}$ nrDNAs [13]. Comparative genome analysis revealed the phylogenetic relationships between these three species and highlighted dramatic structural changes in the cp genome of P. japonicum. We also developed authentication markers to classify the three species. This study provides valuable genetic resources for authenticating three commercially important plant species, as well as for the taxonomical classification of Apiaceae species.

\section{Results}

\subsection{Six Complete Cp Genomes and $45 S$ Nrdna Sequences of Three Apiaceae Species}

Using two accessions each of L. seseloides (Ls-01 and Ls-02), P. japonicum (Pj-01 and Pj-02), and G. littoralis (Gl-01 and Gl-02), 1.06-5.18 Gb of raw WGS data were generated (Table 1). Complete sequences of the cp genomes and $45 \mathrm{~S}$ nrDNA for each accession were successfully assembled using the dnaLCW method. Lengths of the complete cp genomes for each accession were as follows: Ls-01, 147,880 bp; Ls-02, 147,830 bp (Table 1, Figure 1A); Pj-01 and Pj-02, both 164,653 bp (Table 1, Figure 1B); Gl-01 147,467 bp; and Gl-02, 147,477 bp (Table 1, Figure 1C). The gene contents of each cp genome were identical among the six accessions. A total of 120 genes, including 85 protein-coding genes, 31 transfer RNA (tRNA) genes, and four ribosomal RNA (rRNA) genes, were commonly annotated in all cp genomes (Supplementary Table S1).

For each of the three plant species, $45 \mathrm{~S}$ nrDNA sequences were assembled into single contigs, including the complete $45 \mathrm{~S}$ cistron unit (hereafter known as the $45 \mathrm{~S}$ nrDNA unit) (Table 1). As described in a previous study [14], it was not possible to assemble complete IGSs because of gaps at GC-rich 
regions within them, so only $45 \mathrm{~S}$ nrDNA unit sequences were analyzed further in this study. The $45 \mathrm{~S}$ nrDNA units were identical between each of the accessions of a single species, except for a single heterogeneous nucleotide found in L. seseloides (Table S2). Lengths of the $45 \mathrm{~S}$ nrDNA units were identical between L. seseloides and P. japonicum (5185 bp), which was 3 bp longer than G. littoralis (5812 bp) (Table 1).

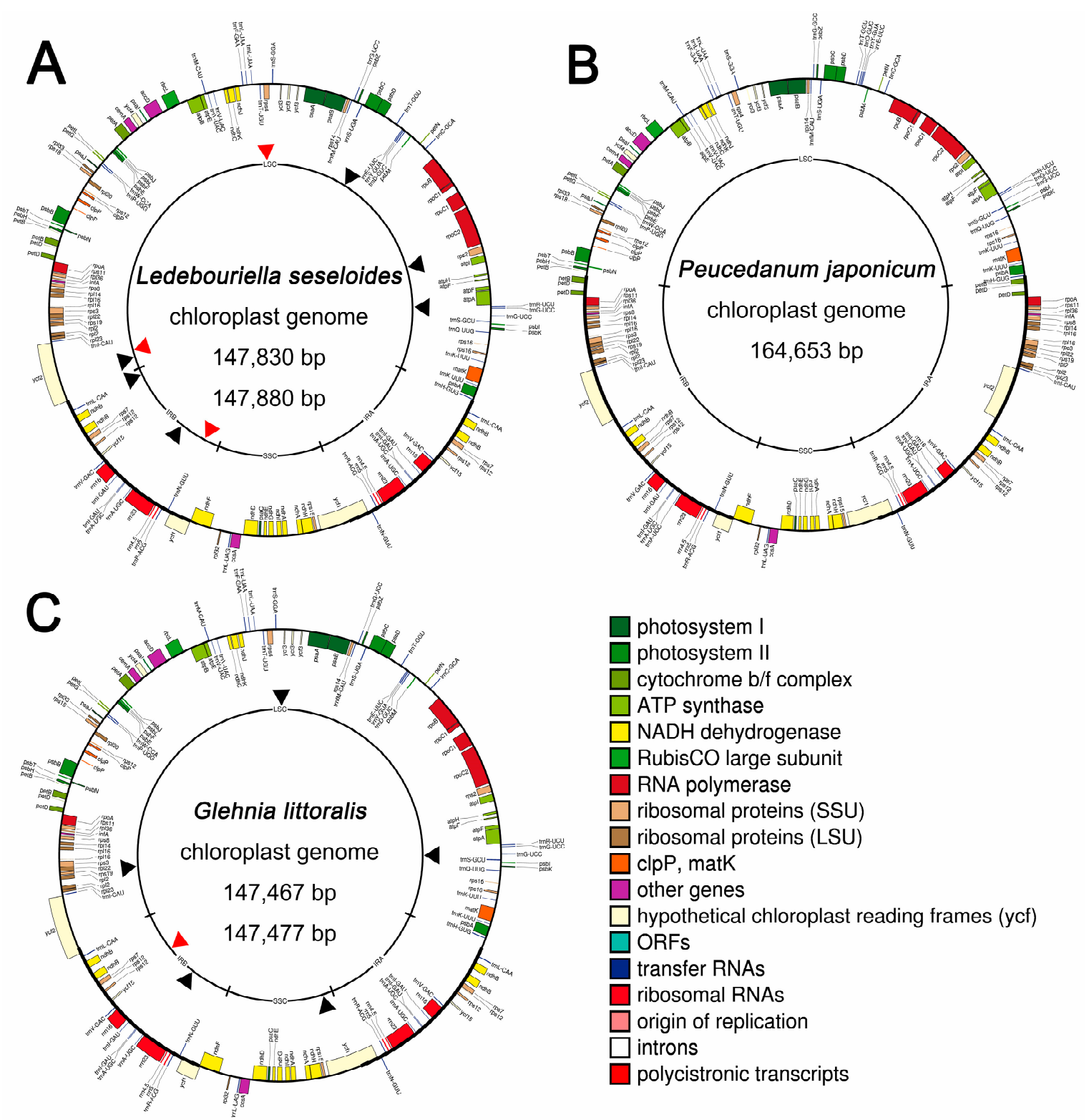

Figure 1. Chloroplast (cp) genome maps of Ledebouriella seseloides (A), Peucedanum japonicum (B), and Glehnia littoralis (C). Colored boxes are conserved cp genes, annotated using the DOGMA program, with manual editing based on BLAST searches. Maps were generated using OGDraw. Genes transcribed clockwise and counterclockwise are indicated on the outside and inside of the large circle, respectively. The intraspecies polymorphic sites 9, 0, and 6 are indicated by black arrowheads for indels and red arrowheads for SNPs in the inner circles of A and C. 
Table 1. Summary of whole-genome sequences generated and assembly status for three Apiaceae species.

\begin{tabular}{|c|c|c|c|c|c|c|c|c|}
\hline \multirow{2}{*}{$\begin{array}{c}\text { Species } \\
\text { (Common Name in } \\
\text { Traditional Korean Medicine) }\end{array}$} & \multirow[b]{2}{*}{ Accession } & \multirow{2}{*}{$\begin{array}{l}\text { Raw Data } \\
\text { (Gbp) }\end{array}$} & \multicolumn{3}{|c|}{ Chloroplast Genome } & \multicolumn{3}{|c|}{ 45S nrDNA } \\
\hline & & & $\begin{array}{l}\text { Length } \\
\text { (bp) }\end{array}$ & $\begin{array}{l}\text { Coverage } \\
\text { (x) }{ }^{d}\end{array}$ & $\begin{array}{l}\text { GenBank Accession } \\
\text { No. (Reference) }\end{array}$ & $\begin{array}{l}\text { Length } \\
\text { (bp) } \mathrm{e}^{\mathrm{s}}\end{array}$ & $\begin{array}{l}\text { Coverage } \\
\text { (x) }{ }^{d}\end{array}$ & $\begin{array}{l}\text { GenBank Accession } \\
\text { No. (Reference) }\end{array}$ \\
\hline \multirow{2}{*}{$\begin{array}{l}\text { Ledebouriella seseloides } \\
\text { (Bang-poong) }\end{array}$} & Ls-01 a & 1.67 & 147,880 & 255.15 & $\begin{array}{c}\text { KT153021 } \\
\text { (Lee et al., 2015a) }\end{array}$ & 5815 & 659.94 & $\begin{array}{l}\text { KX757774 } \\
\text { (This study) }\end{array}$ \\
\hline & Ls-02 b & 5.05 & 147,830 & 177.95 & $\begin{array}{l}\text { KU866529 } \\
\text { (This study) }\end{array}$ & 5815 & 2550.62 & $\begin{array}{l}\text { KX757775 } \\
\text { (This study) }\end{array}$ \\
\hline \multirow{2}{*}{$\begin{array}{l}\text { Peucedanum japonicum } \\
\text { (Sik-bang-poong) }\end{array}$} & $\mathrm{Pj}-01^{\mathrm{a}}$ & 2.08 & 164,653 & 369.41 & $\begin{array}{l}\text { KU866530 } \\
\text { (This study) }\end{array}$ & 5815 & 943.43 & $\begin{array}{l}\text { KX757776 } \\
\text { (This study) }\end{array}$ \\
\hline & $\mathrm{Pj}-02^{\mathrm{b}}$ & 5.18 & 164,653 & 945.25 & $\begin{array}{l}\text { KU866531 } \\
\text { (This study) }\end{array}$ & 5815 & 2418.35 & $\begin{array}{l}\text { KX757777 } \\
\text { (This study) }\end{array}$ \\
\hline \multirow{2}{*}{$\begin{array}{l}\text { Glehnia littoralis } \\
\text { (Hae-bang-poong) }\end{array}$} & Gl-01 c & 1.06 & 147,467 & 146.53 & $\begin{array}{c}\text { KT153022 } \\
\text { (Lee et al., 2015b) }\end{array}$ & 5812 & 399.28 & $\begin{array}{l}\text { KX757778 } \\
\text { (This study) }\end{array}$ \\
\hline & G1-02 b & 4.72 & 147,477 & 367.41 & $\begin{array}{l}\text { KU866532 } \\
\text { (This study) }\end{array}$ & 5812 & 1638.57 & $\begin{array}{l}\text { KX757779 } \\
\text { (This study) }\end{array}$ \\
\hline
\end{tabular}




\subsection{Identification of Intraspecies Variations within Three Apiaceae Cp Genomes}

The cp genome variations are rarely identified at the intraspecies level. Intraspecies sequence variation was investigated by comparing the cp genome sequences of the two accessions of each species (L. seseloides, P. japonicum, and G. littoralis). Nine sequence variations, including six indels and three SNPs, were found between the two accessions of L. seseloides (Figure 1A, Table S3), and six variations, including five indels and a single SNP, were found between the two G. littoralis accessions (Figure 1B, Table S4). No intraspecies sequence variation was present between the two P. japonicum accessions (Figure 1C).

\subsection{IR Expansion and Structural Variations among Three Apiaceae Species}

Interspecies sequence variation was investigated by comparing multiple cp genome sequences of the three plant species. Most genic regions were well conserved compared with intergenic regions, except for several polymorphic genic regions found in $r p o C 2$, ycf1, and ycf2 (Figure S3). Three interesting, large structural changes specific to P. japonicum were identified, and one indel variation within an intergenic region was found in the cp genome of the three species (Figure 2 and Figure S3). A huge IR expansion was found in the P. japonicum cp genome (Figure 2A). Unlike L. seseloides and G. littoralis, the IR regions of $P$. japonicum were greatly expanded to a size of $35,759 \mathrm{bp}-17,546 \mathrm{bp}$ and $17,092 \mathrm{bp}$ longer than those of L. seseloides (18,213 bp) and G. littoralis (18,667 bp), respectively. In P. japonicum, this IR expansion represents an increase in duplicated gene copies for 15 genes $(\inf A, \operatorname{pet} B, \operatorname{pet} D$, rpl14, rpl16, rpl2, rpl22, rpl23, rpl36, rpoA, rps11, rps19, rps3, rps8, and ycf2). We used PCR analysis to validate these expanded IR regions using the junction sequence between IR and LSC in P. japonicum $\mathrm{cp}$ (Figure 2C). Another structural change in P. japonicum compared to the other two species was a 625-bp fragment inversion, which resulted in three genes (trnE-UUC $\sim \operatorname{trn} Y$-GUA $\sim \operatorname{trn} D$-GUC) being oppositely oriented (Figure 2D). Another indel was also identified near this inversion region on the P. japonicum cp genome, which was $454 \mathrm{bp}$ and $435 \mathrm{bp}$ shorter than that of L. seseloides and G. littoralis, respectively. For the G. littoralis $\mathrm{cp}$ genome, an indel variation was found at the intergenic target of $y c f 2 \sim t r n L-C A A$ within the IR region. The sequence length of this region in G. littoralis was $810 \mathrm{bp}$ and $915 \mathrm{bp}$ shorter than that of L. seseloides and P. japonicum, respectively (Figure 2E). Although these three species are relatively closely related, they show dynamic chloroplast genome rearrangement, especially in $P$. japonicum.

\subsection{Tandem Repeats and Copy Number Variations in the Cp Genomes of Three Species}

By comparing the sequences of cp genomes at the interspecies level, 40 copy number variations (CNVs) of tandem repeat (TR) units were found (Table 2). In the cp genomes of L. seseloides, P. japonicum, and G. littoralis, 29, 22, and 11 TRs were found, respectively. TR units ranged in length from 10 to $39 \mathrm{bp}$, with 14-bp TR units being most abundant (7), followed by 17-bp units (4), and 18-bp units (4). Most of the $40 \mathrm{CNVs}$ were present in intergenic regions, and only three were present in genic regions of the $y c f 2$ and $y c f 15$ genes. CNVs of various TR units related to indel polymorphism between the three species were also identified. 


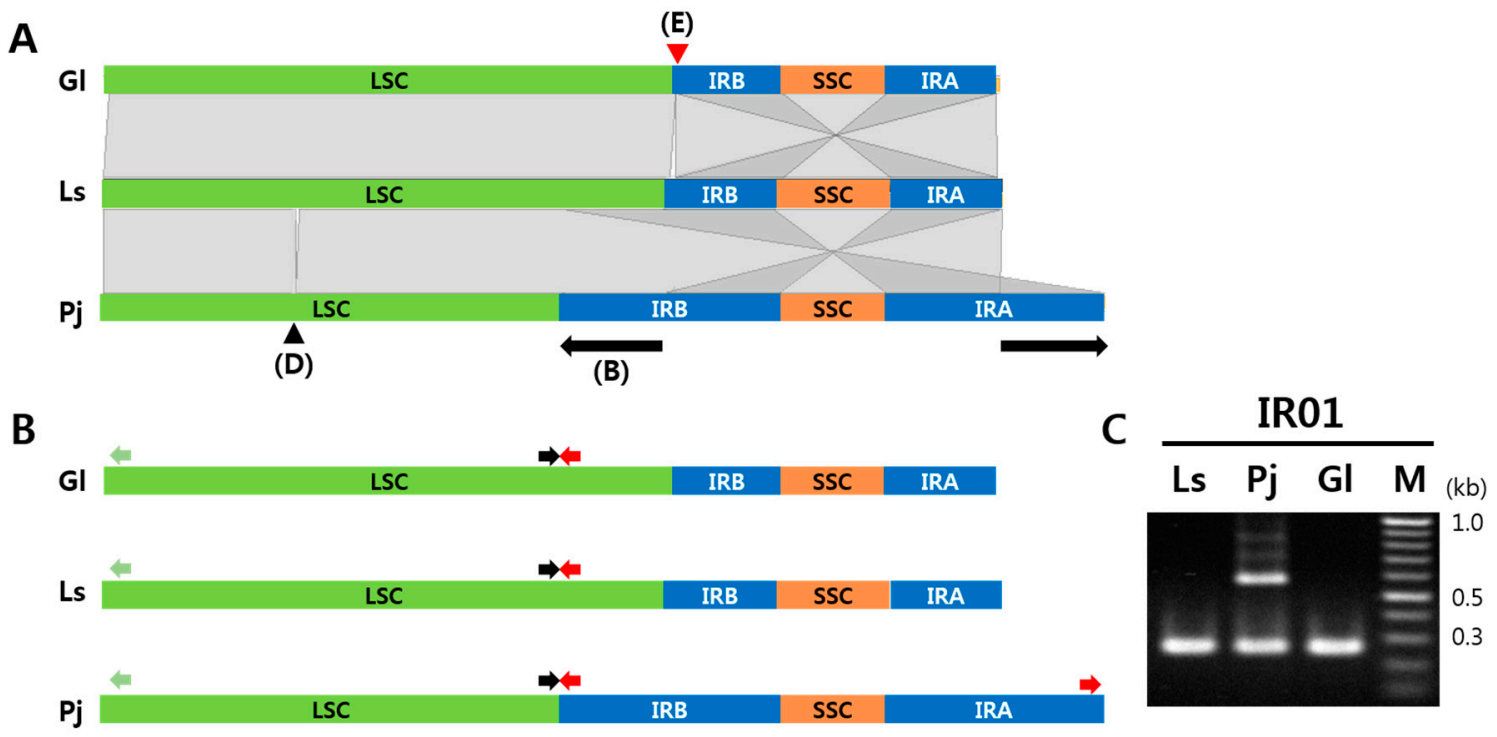

D

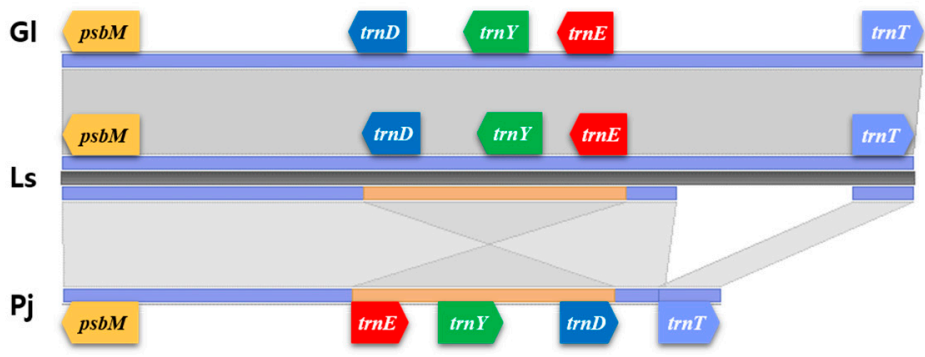

E

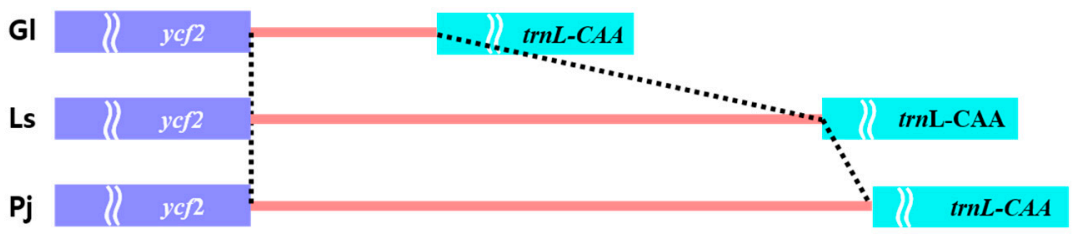

Figure 2. Comparative analysis of chloroplast (cp) genomes structure between the three Apiaceae species. (A) Blast-Z alignment of three species. Expanded inverted repeat (IR) regions (IRA and IRB) found in Peucedanum japonicum are indicated by arrows. (B) Locations of the three primers used to detect IR expansion in the cp genome sequences of three Apiaceae species. Black and red arrows indicate forward and reverse primers for control amplicons amplified in all three species, while the green arrows indicate primers specific to the left proximal junction region of the large single copy (LSC). Note that the site for the control reverse primer (red) is also present in the IRA region of the P. japonicum cp genome, resulting in amplification of one additional DNA fragments. (C) PCR results to validate the IR junction. A DNA fragment of about $0.6 \mathrm{~kb}$ in length was only amplified in P. japonicum, while a DNA fragment of about $0.3 \mathrm{~kb}$ amplified by control primers was detected in all three Apiaceae species. PCR amplicons were analyzed by $1.3 \%$ agarose gel electrophoresis. (D) Gene inversion found in P. japonicum. A 625-bp region, including trnD-GUC, trn Y-GUA, and trnE-UUC, was inverted in P. japonicum (indicated by black arrowhead in A), unlike in Glehnia littoralis and Ledebouriella seseloides. (E) Variable intergenic region between the three species. The $y c f 2 \sim \operatorname{trn} \mathrm{L}-\mathrm{CAA}$ intergenic region (indicated by red arrowhead in A) in G. littoralis (391 bp) was much shorter than those in L. seseloides (1201 bp) and P. japonicum (1306 bp). Ls, L. seseloides; Pj, P. japonicum; Gl, G. littoralis. 
Table 2. Copy number variations of tandem repeat (TR) units in chloroplast (cp) genomes among three Apiaceae species.

\begin{tabular}{|c|c|c|c|c|c|c|}
\hline \multirow{2}{*}{ No. } & \multirow{2}{*}{ TR Unit Sequence } & \multirow{2}{*}{ Unit Length (bp) } & \multicolumn{3}{|c|}{ Copy Number } & \multirow{2}{*}{ Position } \\
\hline & & & Ls & $\mathbf{P j}$ & Gl & \\
\hline 1 & AATAAGTAACTAG & 13 & 2 & 1 & 1 & 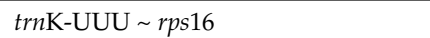 \\
\hline 2 & ТTCТTСТАТАСАAА & 14 & 2 & 2 & 2 & $r p s 16 \sim \operatorname{trn} \mathrm{Q}-\mathrm{UUG}$ \\
\hline 3 & AAAGATATGATTCATA & 16 & 2 & 2 & 1 & $r p s 16 \sim \operatorname{trn} \hat{\mathrm{Q}-U U G}$ \\
\hline 4 & TAAAAAATATAAA & 13 & 2 & 1 & 1 & $\operatorname{atp} \mathrm{F} \sim \operatorname{atpH}$ \\
\hline 5 & AGGAATCATTAAA & 13 & 2 & 1 & 1 & $r p s 2 \sim r p o \mathrm{C} 2$ \\
\hline 6 & TATATTGTTATAAT & 14 & 1 & 1 & 2 & $r p o \mathrm{~B} \sim \operatorname{trn} \mathrm{C}-\mathrm{GCA}$ \\
\hline 7 & TATAATATTAATAAG & 15 & 2 & $\mathrm{nf}$ & $\mathrm{nf}$ & 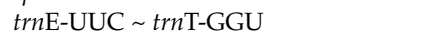 \\
\hline 8 & TATATAGGAAGTATGAT & 17 & $\mathrm{nf}$ & 2 & 1 & $\operatorname{trnS-UGA} \sim \operatorname{lh} b \mathrm{~A}$ \\
\hline 9 & ATCTAGATAAGATTTATA & 18 & 2 & 1 & 1 & 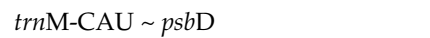 \\
\hline 10 & TTAAATGGTATTTATTAAT & 19 & 2 & 1 & 1 & $\operatorname{trnS}-\mathrm{UGA} \sim \ln b \mathrm{~A}$ \\
\hline 11 & ATTAGCCATTACTAATAG & 18 & 1 & 2 & 1 & $p s a \mathrm{~A} \sim y c f 3$ \\
\hline 12 & TAACCTAAGTGCAAAAATAGA & 21 & 1 & 2 & 1 & $y c f 3 \sim \operatorname{trnS}-\mathrm{GGA}$ \\
\hline 13 & TATTCTATATATATATATTCTATATA & 26 & 1 & 2 & 1 & $r p s 4 \sim \operatorname{trnT}$-UGU \\
\hline 14 & TTTATATATATATATAT & 17 & 2 & 1 & 1 & $n d h \mathrm{C} \sim \operatorname{trn\mathrm {V}-\mathrm {UAC}}$ \\
\hline 15 & TTATCTTTATAATTTAA & 18 & 1 & 2 & 1 & $a c c \mathrm{D} \sim p s a \mathrm{I}$ \\
\hline 16 & TATATGTATATTGA & 14 & 2 & 2 & 1 & $p s a \mathrm{I} \sim y c f 4$ \\
\hline 17 & TTATTCCAGTAAAA & 14 & 2 & 2 & 2 & $\operatorname{cem} \mathrm{A} \sim \operatorname{pet} \mathrm{A}$ \\
\hline 18 & AAGGAAGTACTC & 12 & 1 & 2 & 1 & $p s b \mathrm{E} \sim p e t \mathrm{~L}$ \\
\hline 19 & ATTATATATAT & 11 & $\mathrm{nf}$ & 3 & 1 & 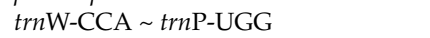 \\
\hline 20 & TTATACAAGGTACTTAAATGTAAA & 24 & 2 & 1 & 1 & $p s a \mathrm{~J} \sim r p l 33$ \\
\hline 21 & TTCTATATAGAACATAATTAAATA & 24 & 2 & 2 & 2 & rpl33 rps 18 \\
\hline 22 & TAAAGTTCCAACTAAAAAG & 19 & 2 & 1 & 2 & $p s b \mathrm{~T} \sim p s b \mathrm{~N}$ \\
\hline 23 & TCСССТTTTT & 10 & 1 & 2 & 1 & $r p s 11 \sim r p l 36$ \\
\hline 24 & ATATTTTTAAATTG & 14 & 2 & 2 & 3 & $r p l 16 \sim r p s 3$ \\
\hline 25 & TCTTATAGAATTAGAATTGT & 20 & 2 & 1 & 1 & $r p l 16 \sim r p s 3$ \\
\hline 26 & CCTATTGCCGATACA & 15 & 2 & 2 & 2 & $y c f 2$ \\
\hline 27 & TAGTGACGATATTGATGC & 18 & $6 / 5^{\mathrm{a}}$ & 4 & 3 & ycf2 (marker ID CNV01) \\
\hline 28 & AAACTCTCTTCAAGAGTTATTAACACCAACCCGGTGTTC & 39 & $\mathrm{nf}$ & 2 & $\mathrm{nf}$ & $y c f 2 \sim \operatorname{trn} \mathrm{L}-\mathrm{CAA}$ \\
\hline 29 & TGGTGGAGATCAGAAAGAGAA & 21 & 2 & 1 & $\mathrm{nf}$ & $y c f 2 \sim \operatorname{trn} \mathrm{L}-\mathrm{CAA}$ \\
\hline 30 & TGTAATGTACTT & 12 & 2 & 1 & 1 & $y c f 2 \sim \operatorname{trn} \mathrm{L}-\mathrm{CAA}$ \\
\hline 31 & TCTTTTCTTCCGTGATGAACT & 21 & 3 & 1 & 1 & ycf 15 \\
\hline 32 & ACCGAAAGGAAAAGCGTGAA & 20 & 2 & 2 & 3 & trnI-GAU $\sim \operatorname{trnI-GAU}$ \\
\hline 33 & CATTGTTCAACTCTTTGACAACACGAAAAAAC & 32 & 2 & 2 & 2 & $r r n 4.5 \sim r r n 5$ \\
\hline 34 & AAAAAGAAATAAAT & 14 & 2 & 2 & 1 & $\operatorname{trnR}$-ACG \\
\hline 35 & ТTCTATTTCTTTTCTATATATG & 22 & 1 & 4 & 1 & $\operatorname{trn} \mathrm{N}-\mathrm{GUU} \sim y c f 1$ (marker ID CNV02) \\
\hline 36 & TATTAATATTAATAAAT & 17 & 2 & $\mathrm{nf}$ & $\mathrm{nf}$ & $y c f 1 \sim n d h \mathrm{~F}$ \\
\hline 37 & TATATATGTATAAA & 14 & 2 & $\mathrm{nf}$ & $\mathrm{nf}$ & $r p l 32 \sim \operatorname{trn} \mathrm{L}-\mathrm{UAG}$ \\
\hline 38 & AAATATTAATCTACTTCT & 18 & 2 & 1 & 1 & $p s a \mathrm{C} \sim n d h \mathrm{E}$ (marker ID CNV03) \\
\hline 39 & TTATGAATATAA & 12 & 2 & 2 & 2 & $p s a \mathrm{C} \sim n d h \mathrm{E}$ \\
\hline 40 & TATTATTTTTTATTA & 15 & 2 & 1 & 1 & $n d h \mathrm{~A} \sim \operatorname{orf} 188$ \\
\hline
\end{tabular}

${ }^{a}$ Copy number variations at the intraspecies level. Ls, Ledebouriella seseloides; $\mathrm{Pj}$, Peucedanum japonicum; and Gl, Glehnia littoralis. nf, not found. 


\subsection{Sequence Variations of $45 S$ DNA Sequences of Three Species}

Comparing the two accessions of each species analyzed in this study, their respective $45 \mathrm{~S}$ nrDNA unit sequences were found to be identical (Table 1), except for a heterogeneous site $(4,482$ nucleotide position) with co-appearance of $\mathrm{T}$ and $\mathrm{C}$ in the L. seseloides $45 \mathrm{~S}$ nrDNA unit sequence (Table S2). At the interspecies level, ITS1 and ITS2 sequences were highly polymorphic compared with the rRNA gene sequences. A total of 66 SNPs was found among the three plant species: 2 in 18S rRNA, 18 in ITS1, 1 in $5.8 \mathrm{~S}$ rRNA, 12 in ITS2, and 33 in $26 \mathrm{~S}$ rRNA regions (Table S2).

\subsection{Phylogenetic Analysis and Divergence Time Estimation}

Using 76 protein-coding genes of 14 Apiaceae species, Bayesian phylogenetic inference analysis was conducted with BEAST (v. 2.4.3). Divergence time was calibrated based on the point at which the Apiaceae and Araliaceae families diverged 49.5 million years ago (Mya). L. seseloides and P. japonicum appeared to be in the same group, which diverged 2.3-3.4 Mya. However, G. littoralis was grouped with Angelica decursiva and Ostericum grosseserratum (Figure 3), which diverged between 1.6 and 2.8 Mya. It is estimated that these two groups branched out from common ancestors between 5.2 and 6.6 Mya. Phylogenetic analysis of $45 \mathrm{~S}$ nrDNA also concurred with cp genome-based phylogeny (Figure S6).

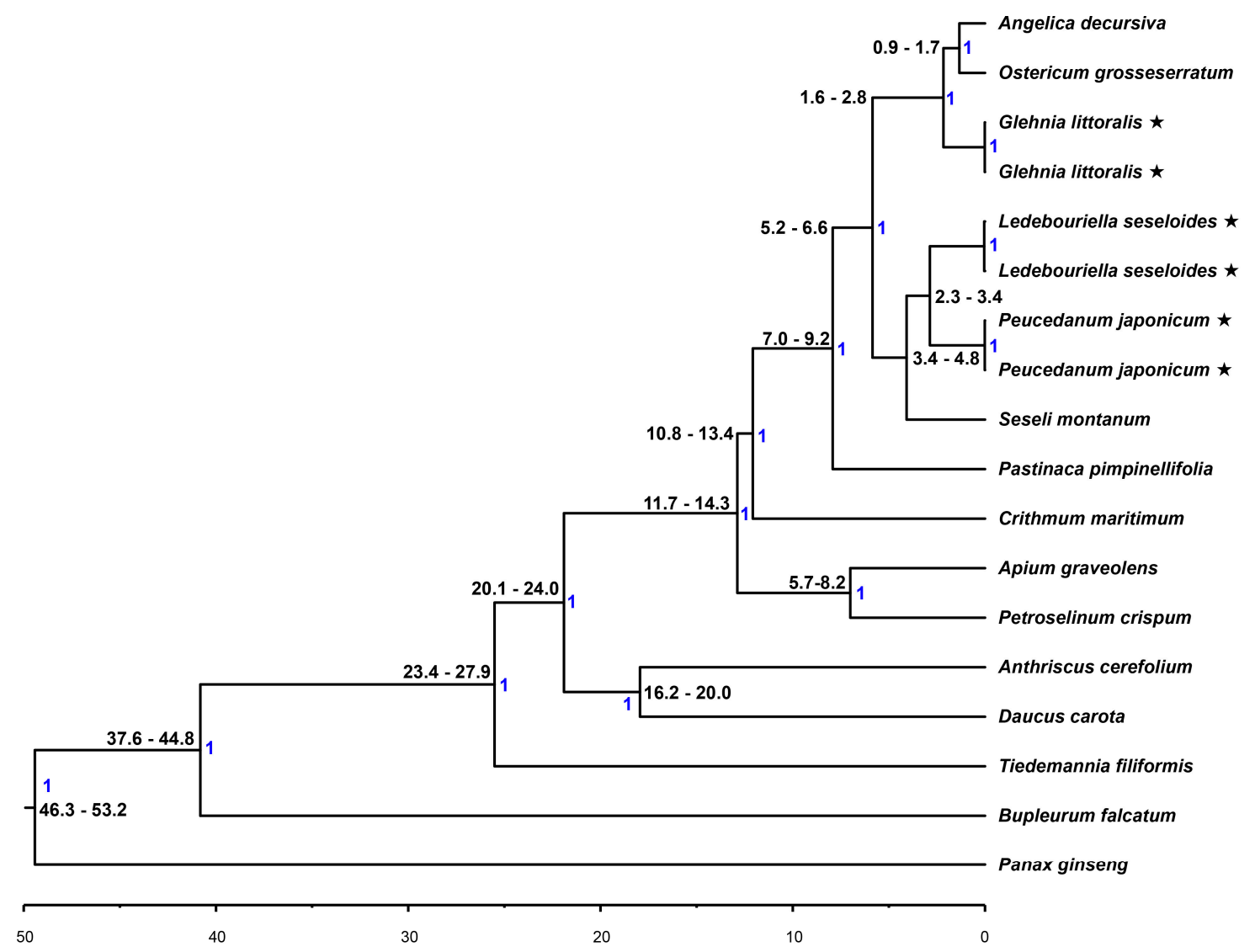

Figure 3. Phylogenetic relationship and estimated divergence time of 14 related Apiaceae species. A phylogenetic tree was constructed with BEAST, using 76 protein coding sequences common to $\mathrm{cp}$ genomes, including those of the Panax ginseng cp genome as an outgroup. Divergence times were estimated based on the divergence time (49 Mya) between Daucus carata (Apiaceae) and P. ginseng (Araliaceae). Posterior probability value indicated by blue color.

\subsection{Comparison of Mutation Rate among All Cp Protein-Coding Genes in the Three Apiaceae Species}

To determine the mutation rate of the 76 protein-coding genes in the cp genome of the three tested plant species, we calculated non-synonymous substitution (Ka) and synonymous substitution (Ks) 
values for each gene and displayed them in a scatterplot. Supporting the phylogenetic analysis, the median values for Ka and Ks were 0.000 and 0.004 between L. seseloides and P. japonicum, respectively; 0.000 and 0.009 between P. japonicum and G. littoralis, respectively; 0.0000 and 0.0072 between L. seseloides and G. littoralis respectively (Figure 4). Genes with higher $\mathrm{Ka}$ than $\mathrm{Ks}$ values $(\mathrm{Ka} / \mathrm{Ks} \geq 1)$ represent positively selected genes during speciation. Between 9 and 11 genes were positively selected in each species. Among these, four genes, matK, rpl20, rps16, and ycf2, had high Ka values (over 0.01) between G. littoralis versus $P$. japonicum/L. seseloides, meaning that these genes might be actively involved in the divergence of $G$. littoralis from the others (Figure 4A,B). On the other hand, one gene, rps18, had a higher Ka value over 0.01 between P. japonicum and L. seseloides (Figure 4C). Sixteen genes showed higher neutral mutation (over $0.2 \mathrm{Ks}$ values) between G. littoralis versus P. japonicum; 13 between G. littoralis versus L. seseloides; and eight between P. japonicum and L. seseloides. Meanwhile, 24, 23, and 27 genes were identical between G. littoralis versus P. japonicum, G. littoralis versus L. seseloides, and $P$. japonicum and L. seseloides, respectively. Nineteen genes were mutually identical among the three species: $n d h B, n d h C, p e t D, p e t N, p s a C, p s a I, p s b D, p s b F, p s b I, p s b J, p s b K, p s b L, p s b M, p s b N, p s b T$, $p s b Z, r p l 36, r p s 4$, and $r p s 14$. Five of these genes ( $p s b F, r p l 36, p e t N, p s b Z$, and $p s b J)$ were well conserved among all 16 Apiaceae family species, while $p s b F$ was also conserved in $P$. ginseng, which belongs to the Araliaceae. Overall, nine genes, ccs A, matK, ndhE, rpl32, rps11, rps12, rps $16, y c f 2$, and $y c f 4$, provide more information for classification of the three species.

\subsection{Development of Barcode Markers Derived from cp Genomes and $45 S$ nrDNA Sequences}

Nine barcode markers were developed to discriminate between each of the three tested plant species (Table 3). These markers were based on length polymorphisms identified by comparing cp genome and $45 \mathrm{~S}$ nrDNA unit sequences at the interspecies level. IR01 was designed from the 17-Kbp IR expansion observed in the P. japonicum cp genomes. The marker comprises three primers: one pair as controls and one LSC primer amplifying the newly expanded junction between LSC and IRs in P. japonicum (Figure 2B). The control primer amplifies all three plant species around $260 \mathrm{bp}$, while the reverse control primer site-located in the IRB and IRA sites of P. japonicum-reacts with the LSC primer and amplifies around $570 \mathrm{bp}$ in $P$. japonicum only (because of the characteristic of this IR region) (Figure 2C).

Markers CNV01 and CNV03 can discriminate all three species with different sized amplicons (Figure 5A,C). CNV02, InDel01, InDel04, and IR01 amplified distinct amplicons in P. japonicum, by which the species could be clearly discriminated from other two species (Figure $2 \mathrm{C}$ and Figure S4). InDel02 and nrDNA01 amplified distinct amplicons in G. littoralis; thus, G. littoralis could be discriminated from the other two species (Figures S4 and S5). InDel03 generated a distinct amplicon only in L. seseloides to specifically detect this species. Although PCR amplicons with slightly different sizes ( $<3 \mathrm{bp}$ ) were identified among the three species, the size differences were ignored in this study because of the low separating power of electrophoresis using agarose gel. The marker nrDNA01 was designed to detect SNPs present only in ITS1 of G. littoralis $45 \mathrm{~S}$ nrDNA sequences and was also successfully validated by PCR analysis (Figure S5). Proper combination of nine polymorphic markers can be applied for clear authentication of the three species. 
A

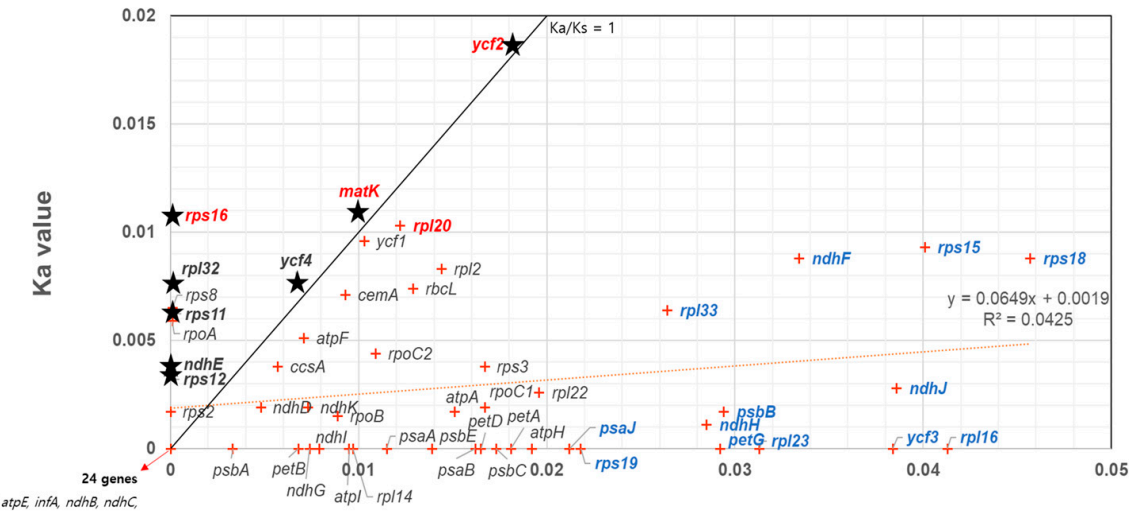

Ks value

rpl36, rps 14, rps4, rps

B

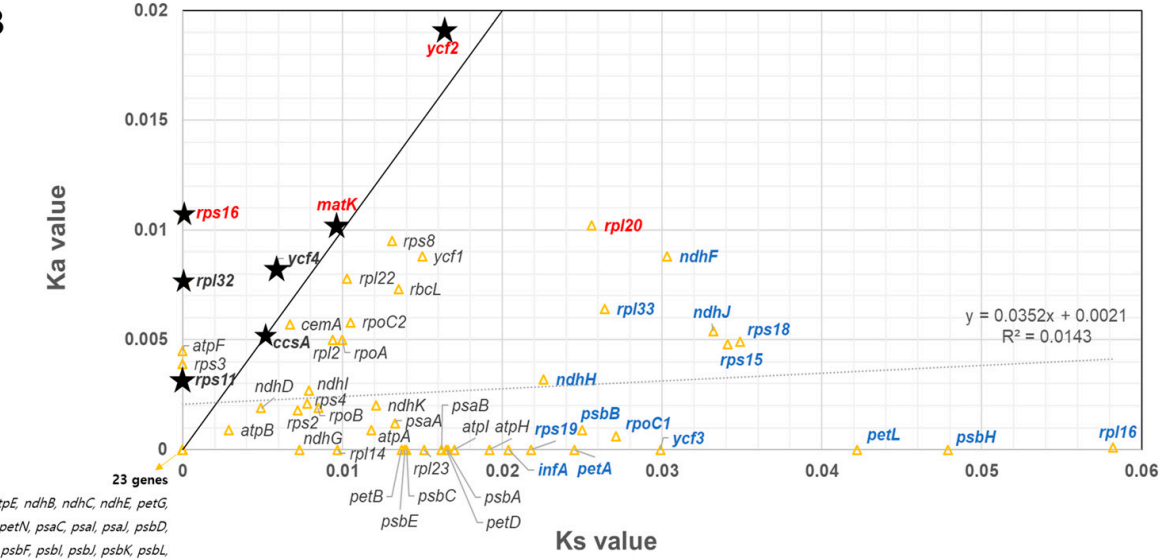

psbe, psol, psbj, psok, psbl

rps 12, rps 14, rps?

C

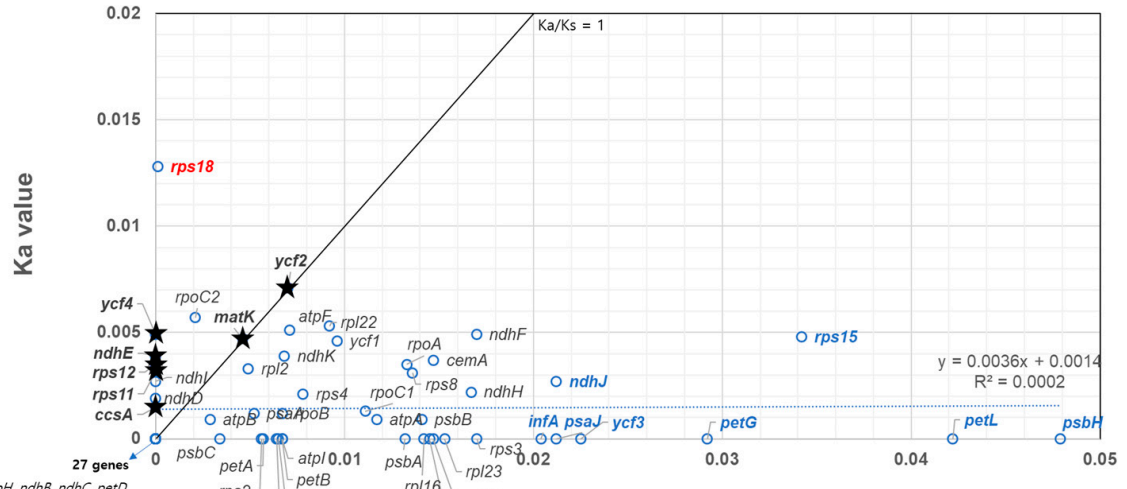

atpE, atph, ndhB, ndh C, petD,

petN, psaC, psal, psbD, psbE,

$\rho s b F, p s b l, p s b l, p s b K, \rho s b l$

$p s b M, p s b N, p s b T, p s b Z$, rplit

ro/32, ro/33, rol36, rps 14, rpos 16,
rps 19, ros 7

Ks value

Figure 4. Chloroplast (cp) gene selection pressure of three Apiaceae species. Scatterplot of non-synonymous substitution (Ka) and synonymous substitution (Ks) values between Ledebouriella seseloides and Glehnia littoralis (A); between Peucedanum japonicum and G. littoralis (B); and between L. seseloides and P. japonicum (C). Ka and Ks values were calculated using CodeML and 76 protein-coding genes. Ka and Ks values are represented on the y-axis and x-axis, respectively. $R^{2}$ indicates a trend line. Red letters indicate genes with a Ka value greater than 0.01 , and blue letters indicate genes with a Ks value greater than 0.02 . Genes marked by an asterisk $\left(^{*}\right)$ are commonly positively selected genes in at least two analysis results. Ls, L. seseloides; Pj, P. japonicum; and Gl, G. littoralis. 
Table 3. Barcode markers developed in this study.

\begin{tabular}{|c|c|c|c|}
\hline \multirow{2}{*}{ Marker ID } & \multirow{2}{*}{ Primer Sequence $\left(5^{\prime}-3^{\prime}\right)$} & Product Size $^{a}$ & \multirow{2}{*}{ Location } \\
\hline & & Ls/Pj/Gl (bp) & \\
\hline \multirow{2}{*}{ CNV01 } & F: GGTCAAATACCTAGCGACAA & \multirow{2}{*}{$308 / 272 / 254$} & \multirow{2}{*}{$y c f 2$} \\
\hline & R: TTATGCAAGGAGACATTGCT & & \\
\hline \multirow{2}{*}{ CNV02 } & F: CATCCATATCCCAATTCCAT & \multirow{2}{*}{$305 / 371 / 305$} & \multirow{2}{*}{$\operatorname{trnN-GUU\sim ycf1}$} \\
\hline & R: GCTCGGAGAAGGAAGAGATA & & \\
\hline \multirow{2}{*}{ CNV03 } & F: CATTGAGTGCACCCTATACA & \multirow{2}{*}{$404 / 386 / 368$} & \multirow{2}{*}{$p s a C \sim n d h E$} \\
\hline & R: TCGTAACAGAAAATCAACTCG & & \\
\hline \multirow{2}{*}{ InDel01 } & F: AACGAATCCTACGGTTTCTC & \multirow{2}{*}{$266 / 289 / 269$} & \multirow{2}{*}{$\operatorname{trnS}-G C U \sim \operatorname{trnR}-U C U$} \\
\hline & R: TGTCGAACAGGGATAATTTG & & \\
\hline \multirow{2}{*}{ InDel02 } & F: TCTCGCTTTTTAGTCAGTTTG & \multirow[t]{2}{*}{$380 / 379 / 416$} & \multirow[t]{2}{*}{$n d h F \sim r p l 32$} \\
\hline & R: GCCTAATGAAAAGCCTAATGA & & \\
\hline InDel03 & F: CAGGAGGATAGCAAGTTACAA & \multirow[t]{2}{*}{$412 / 571 / 571$} & $r p s 12 \sim \operatorname{trn} V-G A C$ \\
\hline \multirow{3}{*}{ InDel04 } & $\begin{array}{l}\text { R: CAACGCCACTATTCTTGAAC } \\
\text { F: CTATATGTATATACAATAACGAATCA }\end{array}$ & & \multirow{2}{*}{$\operatorname{trn} E-U U C \sim \operatorname{trn} T-G G U$} \\
\hline & R: GTTCAAGAATAGTGGCGTTG & $652 / 198 / 633$ & \\
\hline & LSC P: CCTAGCTGCTGTTGAAGCTC & na/576/na & psbA \\
\hline \multirow[t]{3}{*}{ IR01 } & Control F: GACGACTGAGCCAACTTGAT & \multirow{2}{*}{$262 / 262 / 262$} & \multirow{2}{*}{$p s b H \sim p e t B$} \\
\hline & Control R: TCGAGACGTTCTTCAAACCA & & \\
\hline & Specific F: GTTAACAATTAGGGCGAGCA & na/na/291 & ITS1 \\
\hline \multirow{2}{*}{ nrDNA01 } & Control F: GCATCGATGAAGAACGTAGC & \multirow{2}{*}{ 78/78/78 } & \multirow{2}{*}{$5.8 \mathrm{~S}$} \\
\hline & Control R: GCGTTCAAAGACTCGATGGT & & \\
\hline
\end{tabular}

a Amplicon size expected for each of the three species. Ls, Ledebouriella seseloides; $\mathrm{Pj}$, Peucedanum japonicum; and Gl, Glehnia littoralis. na, not amplified.

A
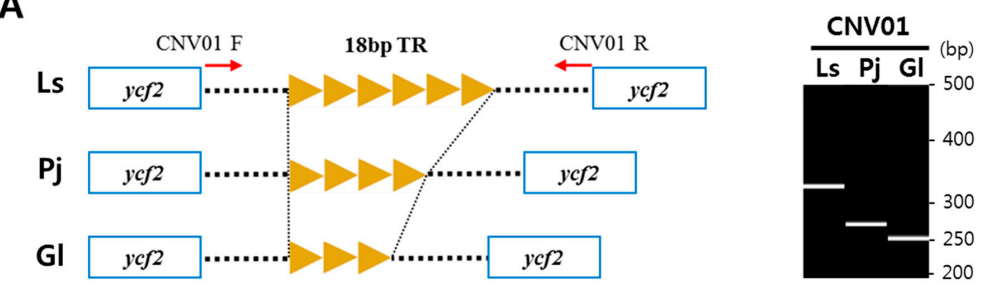

B
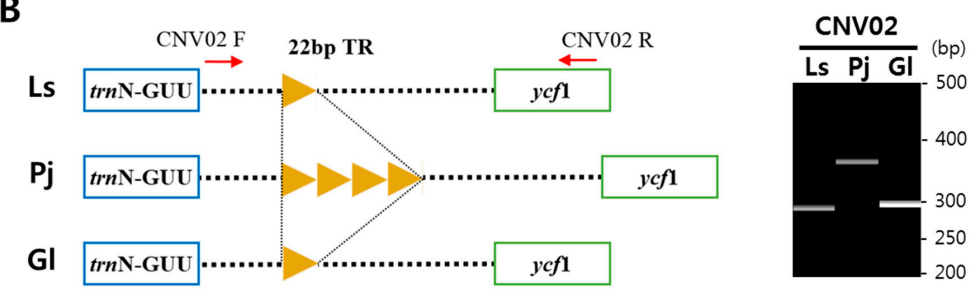

C

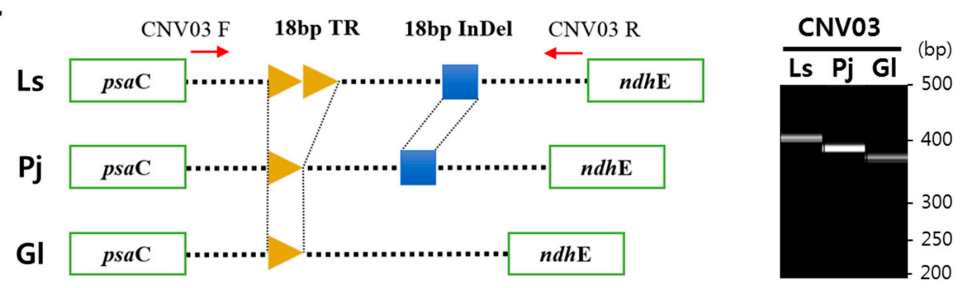

Figure 5. Schematic diagram and digital gel images from capillary electrophoresis of barcode markers derived from copy number variations (CNVs) of tandem repeat (TR) units in chloroplast genome. (A) Six, four, and three copies of an 18-bp TR unit were found in intergenic regions of trnI-CAU trnL-CAA in Ledebouriella seseloides, Peucedanum japonicum, and Glehnia littoralis. (B) Four copies of a 22-bp TR unit were found in the intergenic region of trnN-GUU ycf1 in P. japonicum. (C) Two copies of an 18-bp TR unit were found in the intergenic region of $p s a C \sim n d h E$ in L. seseloides, and insertion of an 18-bp sequence was also found in the regions of L. seseloides and P. japonicum. Red arrows indicate primers used for PCR analysis. The size differences of PCR amplicons are shown on the right side of the schematic diagram. Ls, L. seseloides; Pj, P. japonicum; Gl, G. littoralis. CNV01, CNV02, and CNV03 indicate marker IDs. 


\section{Discussion}

\subsection{Molecular Phylogeny of the Apiaceae Species}

The taxonomic classification of Apiaceae species has not been established. The taxonomic classification system proposed by Drude [15] was based on broad inspection; for example, fruit morphology and anatomy. Though later modified, this approach remains widely accepted for discriminating Apiaceae species. Molecular classification based on DNA barcoding markers-an approach proposed by the Consortium for the Barcode of Life (CBOL) — proved to be an easy and accurate way of discriminating plant species and led to further clarifications of plant diversity and evolution. A previous study proposed that Peucedanum species are closely related to Angelica species [16]. Our data, which are based on complete cp genomes and 45S nrDNA, indicate that G. littoralis is actually more closely related to Angelica species.

\subsection{Intraspecies Chloroplast Variation and DNA Barcoding Markers for Species Authentication}

$\mathrm{Cp}$ genomes are generally conserved and thus have been considered to have little polymorphism at the intraspecies level [9]. However, comparisons of diverse and complete cp genomes have revealed varying amounts of intraspecies polymorphism. The cp genomes of 14 ginseng accessions contained 12 polymorphisms: six indels and six SNPs [14]. Here, we identified intraspecies polymorphism in L. seseloides and G. littoralis, but not in P. japonicum. L. seseloides showed the most diverse intraspecies polymorphism: six SNPs and three InDels. L. seseloides is not indigenous to Korea, but rather was imported from China as a processed medicinal product. We assume that the two collections studied here originate from different locations in China. G. littoralis is indigenous to Korea and, between the two accessions collected from different eastern coastal areas of Korea, six polymorphisms were identified: five SNPs and one indel. By contrast, the two P. japonicum accessions analyzed had identical cp genome sequences, even though they were collected from different sites. Despite this evidence, we hesitate to conclude that P. japonicum has such narrow genetic diversity. Because this species is now cultivated in Korea and Japan, it is possible that the two individual plants sampled here may have been derived from the same cultivated genotype.

Intraspecies polymorphic sites are useful for the classification of a genotype within a species and can be utilized as specific markers for a cultivar, such as in the study of ginseng [14]. However, intraspecies polymorphic sites should be excluded for the development of barcoding markers because they may confuse the process of species authentication $[17,18]$. In this study, we developed nine barcoding markers that can authenticate each species by avoiding the intraspecies polymorphic sites for each species. We suggest using several markers together for species authentication to account for any as-yet unidentified intraspecies diversity.

\subsection{Unique Structural Changes in the cp Genome of P. japonicum}

Our data revealed dynamic structural changes in the cp genome of P. japonicum. Our cp genome sequence data showed that the P. japonicum and L. seseloides are more closely related, and G. littoralis is more diverged. However, L. seseloides and G. littoralis have common cp genome structures, while $P$. japonicum showed three unique structural changes as an expansion of IR sequences, inversion of three tRNA genes, and a deletion near to the inverted region. The inversion and deletion show no association but seemed to result from independent mutations (Figure 2A-C and Figure S3).

Considering that IRs may be involved in rearrangement and stabilization of the cp genome [19], IR expansion might induce structural modifications in the P. japonicum cp genome, such as gene inversion in recent years (Figure 2D). Previously proposed hypotheses for possible mechanisms of IR expansion or contraction involve plastome rearrangement within cp genomes during evolution via recombination between poly A regions [20], repeated sequences [21], and/or duplication or deletion of a certain gene through inversion [22]. Such rearrangements may alter the stability of the genomic structure, which in turn could cause an IR boundary shift. The three structural changes described 
here for P. japonicum could have occurred together or could have been triggered by each other after divergence from L. seseloides 2.3-3.4 Mya (Figure 3).

\subsection{Variation in the cp Genomes and $45 S$ nrDNA of Three Species}

Although the same genes were present in the cp genomes of the three tested plant species, they had many sequence variations at the interspecies level. As expected, most genic regions were more highly conserved than the intergenic regions in the cp genomes. However, some genic regions, such as $r p o C 2, y c f 1$, and $y c f 2$, were polymorphic among the three species. Such genic regions have been used for barcoding regions in other plant species $[13,14,23,24]$, indicating that these genic regions are hotspots of sequence polymorphism (Figure S3 and Table 2). Nineteen genes ( $n d h B, n d h C$, petD, pet $N, p s a C, p s a I$, $p s b D, p s b F, p s b I, p s b J, p s b K, p s b L, p s b M, p s b N, p s b T, p s b Z, r p l 36, r p s 4$, and $r p s 14)$ were conserved among the three species; five of which ( $p s b F, r p l 36, p e t N, p s b Z$, and $p s b J)$ were well conserved in the Apiaceae family, and one of them ( $p s b F)$ remained in the Araliaceae. These genes were considered fundamental genes in Apiales cp genome evolution, and thus not suitable for classifying species.

The $45 \mathrm{~S}$ nrDNA sequences generally show high variation in their ITS1 and ITS2 regions [25]. In the current study, rich variations were observed in 26S rDNA, followed by ITS1, ITS2, 18S rDNA, and 5.8S rDNA. Nevertheless, ITS1 and ITS2 regions remained efficient regions in which to search for DNA barcoding markers because they are simple and quick for PCR validation using universal primer sets. However, our data suggest that the $26 \mathrm{~S}$ rDNA gene region may also be a good candidate to target for barcoding regions [26].

\subsection{Cp Gene Selection Pressure and Phylogenetic Relationship of Three Apiaceae Species}

The ratio between nonsynonymous (Ka) and synonymous (Ks) nucleotide substitution has been widely used in studies to compare genome or gene evolution rates [27]. Overall, Ka and Ks values were higher between G. littoralis and either P. japonicum or L. seseloides than between P. japonicum and L. seseloides. The genes rps16, mat $K$, and $y c f 2$ were under positive selection, showing the highest Ka values, over 0.01 , between $G$. littoralis and the other two species. We conclude that these three genes might have been actively involved in the divergence of $G$. littoralis from the other species (Figure 4A,B). However, only one gene, rps18, showed positive selection, with a Ka value over 0.01, between P. japonicum and L. seseloides (Figure 4C). These positively selected genes may be used more effectively for species classification in Apiaceae species (Figure 4). In fact, ycf2 was used to distinguish between these three species (Figure 2E).

Many studies have reported phylogenetic relationships between members of the Apiaceae family using partial cp genic regions such as rpoC1, rpl16, matK, and $r b c L$ [16,28-30], intergenic regions of trnH-psbA, and trnQ-trnK [31,32], and ITS regions of 45S nrDNA [33-35]. Nevertheless, to date, there has been no comprehensive phylogenic study of these three Apiaceae species, L. seseloides, P. japonicum and G. littoralis. Here, we used complete $\mathrm{cp}$ and $45 \mathrm{~S}$ nrDNA sequence information to phylogenetically analyze the three species and other Apiaceae. Although L. seseloides and G. littoralis were more structurally similar, and $P$. japonicum showed three unique structural variations, our phylogenetic analysis revealed that $L$. seseloides was more closely related to P. japonicum than to G. littoralis (Figure 4).

Molecular clock analysis will be interesting to see how the unique cp genome structures changes in the P. japonicum cp genome during this period. Inspection of more cp genomes of other species that are closely related to $P$. japonicum should clarify to reveal how and when the chloroplast genome structure was changed in P. japonicum lineage.

\section{Materials and Methods}

\subsection{Plant Materials}

In this study, we conducted sequencing and assembly of the cp genomes and 45S nrDNA of three Apiaceae species, L. seseloides, P. japonicum, and G. littoralis. Two individual plant samples of each 
species were collected; one from each of two different locations (Table 1). L. seseloides plants were collected from China, and P. japonicum and G. littoralis were collected from South Korea. All plants were maintained in the medicinal plant gardens at Seoul National University and the Ministry of Food and Drug Safety, South Korea.

\subsection{Genomic DNA Preparation and Whole-Genome Shotgun Sequencing}

Total genomic DNA was extracted from leaves using a modified cetyltrimethylammonium bromide (CTAB) method [36]. The quantity and quality of genomic DNA was examined using a UV-spectrophotometer (Thermo Scientific Nanodrop ND-1000, Waltham, MA, USA) and agarose gel electrophoresis. For WGS, genomic libraries with a 300-bp insert size were prepared according to the standard paired-end (PE) protocol (Illumina, San Diego, CA, USA) and sequenced by the National Instrumentation Center for Environmental Management (http://nature.snu.ac.kr/kr.php), Seoul, Korea, using an Illumina genome analyzer (HiSeq2000). The library for each plant sample was separately tagged with a different Illumina index and pooled for sequencing in a single lane. After sequencing 101 cycles, PE reads for each plant sample were collected according to the index.

\subsection{Cp Genome and $45 S$ nrDNA Assembly}

We assembled complete cp genome sequences of accessions Ls-01 (KT153021) and Gl-01 (KT153022) in previous work $[37,38]$. Complete cp genomes and $45 \mathrm{~S}$ nrDNA sequences of the remaining samples were generated using the dnaLCW method, as described by Kim et al. [13,14]. In brief, trimmed, high-quality reads with Phred scores of 20 or greater were obtained from the total PE reads using the CLC-quality trim tool and then were assembled using a CLC genome assembler (version 4.06 beta, CLC Inc, Aarhus, Denmark).

Initial contigs of the cp genome were selected using Panax ginseng (KM088019) [14] and Daucus carota (NC_008325) [39] as reference sequences with MUMmer [40]. cp contigs were then ordered based on reference cp sequences and merged into a single draft sequence by connecting overlapping terminal sequences. The draft cp sequences were curated manually by re-mapping raw WGS reads. Average coverage of mapped reads ranged between 146.53x and 945.25x (Table 1 and Figure S1).

For $45 \mathrm{~S}$ nrDNA assembly, the longest initial contigs, including the $45 \mathrm{~S}$ cistron unit, were selected by comparing with reported $45 \mathrm{~S}$ nrDNA sequences of Panax ginseng (KM036295). The average coverage of raw PE reads mapped to $45 \mathrm{~S}$ nrDNA sequences ranged between $399.28 \times$ and $2550.62 \times$ (Table 1 and Figure S2). Assembly errors and gaps found in the draft sequences were manually corrected by mapping raw WGS reads.

\subsection{Gene and Structural Annotation}

The cp genes were annotated using DOGMA (http://dogma.ccbb.utexas.edu/) [41], with manual curation based on BLASTN searches. Circular maps of each cp genome were drawn using OGDRAW (http://ogdraw.mpimp-golm.mpg.de/) [42]. The structures of $45 \mathrm{~S}$ nrDNA sequences were predicted by RNAmmer (http://www.cbs.dtu.dk/services/RNAmmer/) and BLASTN searches against the National Center for Biotechnology Information nucleotide database (https://blast.ncbi.nlm.nih.gov/Blast.cgi).

\subsection{Comparative Sequence Analysis at the Intraspecies and Interspecies Level}

To characterize intraspecies and interspecies variation, six cp genome and $45 \mathrm{~S}$ nrDNA sequences were aligned with MAFFT (http://mafft.cbrc.jp/alignment/server/) [43], and sequence variations were visualized using mVISTA (http://genome.lbl.gov/vista/mvista/submit.shtml) [44] with the Shuffle LAGAN alignment program [45] and the BlastZ tool [46]. Some misaligned regions were manually curated using BioEdit (http://www.mbio.ncsu.edu/bioedit/bioedit.html). Then, polymorphic regions showing SNPs and indels were investigated at the intraspecies and interspecies levels. 


\subsection{Development and Validation of DNA Barcode Markers}

Using Primer 3 (http://bioinfo.ut.ee/primer3-0.4.0/), primers were designed from polymorphic sites of those cp genomes and $45 \mathrm{~S}$ nrDNA sequences with interspecies diversity but no intraspecies variation. Amplification of marker was implemented with $20 \mathrm{ng}$ of genomic DNA from three species in a $25 \mu \mathrm{L}$ reaction volume containing $10 \times$ buffer, dNTP and Taq mixture (Inclone biotech, Gyonggido, Korea) with 10 pmol of each primer. Amplification was performed on Veriti 96-Well Thermal Cycler (Advanced Analytical Technologies Inc., Santa Clara, CA, USA) under the following conditions: initial denaturation at $94{ }^{\circ} \mathrm{C}$ for $5 \mathrm{~min}$, followed by 35 cycles of denaturation at $94{ }^{\circ} \mathrm{C}$ for $90 \mathrm{~s}$, annealing at $54{ }^{\circ} \mathrm{C}$ for $90 \mathrm{~s}$, and extension at $72{ }^{\circ} \mathrm{C}$ for $90 \mathrm{~s}$, and final extension at $72{ }^{\circ} \mathrm{C}$ for $7 \mathrm{~min}$. Amplified PCR fragments were analyzed with electrophoresis by $1.3 \%$ agarose gels at $100 \mathrm{~V}$ for $20 \mathrm{~min}$, and also with a capillary electrophoresis instruments known as fragment analyzer, with DNF- 905 Kit (Advanced Analytical Technologies Inc.), under following condition according to the manufacturer's instructions. Digital gel images of amplificon were generated from Prosize 2.0 program (Advanced Analytical Technologies Inc. https://www.aati-us.com/support/software/).

\subsection{Calculation of Nucleotide Substitution Value}

The non-synonymous substitution (Ka) to synonymous substitution (Ks) ratio was calculated with the maximum likelihood method using CodeML (Berkeley, CA, USA, version $4.9 \mathrm{~h}$ ) [47]. To avoid duplication, only one copy of the gene in IRs was used in the analysis. For ycf1, the difference in length of smaller copies was eliminated. The average values of Ka, Ks, and Ka per Ks were calculated for 76 protein-coding genes (Supplementary Data S1).

\subsection{Phylogenetic Analysis}

Phylogenetic relationships between cp genomes were estimated using 15 species (representing 18 accessions) in the Apiales order (Apiaceae + Araliaceae) as follows: Angelica decursiva (KT781591), Anthriscus cerefolium (NC_015113), Apium graveolens (NC_041087), Bupleurum falcatum (NC_027834), Crithmum maritimum (HM596072), D. carota (NC_008325), G. littoralis (KT153022, KU866532), L. seseloides (KT153021, KU866529), O. grosseserratum (KT852844), P. ginseng (NC_006290), Pastinaca pimpinellifolia (NC_027450), Petroselinum crispum (HM596073), P. japonicum (KU866530, KU866531), Seseli montanum (NC_027451), and Tiedemannia filiformis (HM596071). Phylogenetic analysis was conducted in Yule speciation prior, GTR $+\mathrm{I}+\Gamma$ substitution, and a strict clock model using BEAST (Auckland, New Zealand, version 2.4.3) [48]. Two independent Markov chain Monte Carlo runs were also performed for $10,000,000$ generations, and trees were sampled every 100 steps. We used the same 76 protein-coding genes as in the above nucleotide substitution analysis. Phylogeny of $45 \mathrm{~S}$ nrDNA was constructed to support relationships between the three Apiaceae species (L. seseloides, P. japonicum, and G. littoralis) using the same programs and parameters as mentioned above.

Supplementary Materials: Supplementary materials can be found at http://www.mdpi.com/1422-0067/20/9/2196/ s1. Figure S1. Complete cp genome assemblies of L. seseloides (A), P. japonicum (B), and G. littoralis (C). Figure S2. Schematic diagram of $45 \mathrm{~S}$ nrDNA cistron unit of L. seseloides (A), P. japonicum (B), and G. littoralis (C). Figure S3. Comparison of cp genome sequences of three Apiaceae species at inter-species level. Figure S4. Validation of InDel markers. Figure S5. Development and validation of barcode marker nrDNA01 derived from G. littoralis 45S nrDNA unit sequence. Figure S6. Phylogenetic tree of three Apiaceae species using 45S nrDNA sequence. Table S1. Gene contents of cp genomes in three Apiaceae species. Table S2. Cp genome sequence variation of $L$. seseloides between two accessions at the intraspecies level. Table S3. Cp genome sequence variation of G. littoralis between two accessions at the intraspecies level. Supplementary Data S1: Ka and Ks analysis results between the three species.

Author Contributions: Conception and design: H.O.L., K.K., and J.Y.P.; provision of samples for experimentation: S.K., M.K., K-y.K., and W.K.L.; experiments: H.J.J. and H.O.L.; annotation: M.-S.P.; data analysis; H.O.L. and H.J.J.; data interpretation: all author; writing: H.O.L. and H.J.J.; review: S.-C.L., N.-H.K., H.-S.P., J.Y.P., and T.-J.Y.

Funding: This work was supported by “The Genetic and Genomic Evaluation of Indigenous Biological Resources 2012" from the National Institute of Biological Resources under the Ministry of Environment and the "Cooperative 
Research Program for Agriculture Science \& Technology Development (Project No. PJ13238)", Rural Development Administration, Republic of Korea.

Acknowledgments: We thank S.C. Lee for reviewing the manuscript and Yungbok Baek of Yeongdeok-gun County Office, Gyeongsangbuk-do, Korea, for providing the G. littoralis plant materials.

Conflicts of Interest: The authors declare no conflict of interest.

\section{References}

1. Pimenov, M.G.; Leonov, M.V.E. The genera of the Umbelliferae: A nomenclator. In Kew Bulletin; Royal Botanic Gardens, Kew: Richmond, UK, 1993; Volume 49, pp. 592-593.

2. Wu, Z.; Raven, P.H.; Hong, D. Flora of China. Volume 14: Apiaceae through Ericaceae; Science Press: Beijing, China, 2005; p. 581.

3. Commission, C.P. Pharmacopoeia of the People's Republic of China; China Medical Science and Technology Press: Beijing, China, 2015.

4. Committee, J. The Japanese Pharmacopoeia, 16th ed.; The Ministry of Health, Labour and Welfare: Tokyo, Japan, 2011; p. 2319.

5. Bae, K. The Medicinal Plants of Korea; Kyo-Hak Publishing: Seoul, Korea, 2000; p. 461.

6. Hsu, H.; Chen, Y.; Sheu, S.; Hsu, C.; Chen, C.; Chang, H. Oriental Materia Medica: A Concise Guide; Oriental Healing Arts Institute: Long Beach, CA, USA, 1986; p. 582.

7. Bell, C.R.; Constance, L. Chromosome numbers in Umbelliferae. II. Am. J. Bot. 1960, 47, 24-32. [CrossRef]

8. Constance, L.; Chuang, T.I.; Bell, C.R. Chromosome numbers in Umbelliferae. V. Am. J. Bot. 1976, 63, 608-625. [CrossRef]

9. Ali, M.A.; Gyulai, G.; Hidvegi, N.; Kerti, B.; Al Hemaid, F.M.; Pandey, A.K.; Lee, J. The changing epitome of species identification-DNA barcoding. Saudi J. Biol. Sci. 2014, 21, 204-231.

10. Sugiura, M. The chloroplast genome. Plant Mol. Biol. 1992, 19, 149-168. [CrossRef]

11. Álvarez, I.; Wendel, J.F. Ribosomal ITS sequences and plant phylogenetic inference. Mol. Phylogenet. Evol. 2003, 29, 417-434. [CrossRef]

12. Hollingsworth, M.L.; Andra Clark, A.; Forrest, L.L.; Richardson, J.; Pennington, R.T.; Long, D.G.; Cowan, R.; Chase, M.W.; Gaudeul, M.; Hollingsworth, P.M. Selecting barcoding loci for plants: Evaluation of seven candidate loci with species-level sampling in three divergent groups of land plants. Mol. Ecol. Res. 2009, 9, 439-457. [CrossRef] [PubMed]

13. Kim, K.; Lee, S.-C.; Lee, J.; Yu, Y.; Yang, K.; Choi, B.-S.; Koh, H.-J.; Waminal, N.E.; Choi, H.-I.; Kim, N.-H. Complete chloroplast and ribosomal sequences for 30 accessions elucidate evolution of Oryza AA genome species. Sci. Rep. 2015, 5, 15655. [CrossRef] [PubMed]

14. Kim, K.; Lee, S.-C.; Lee, J.; Lee, H.O.; Joh, H.J.; Kim, N.-H.; Park, H.-S.; Yang, T.-J. Comprehensive survey of genetic diversity in chloroplast genomes and 45S nrDNAs within Panax ginseng species. PLoS ONE 2015, 10, e0117159. [CrossRef] [PubMed]

15. Drude, O. Die naturlichen Pflanzenfamilien (Engler, A.) 3. In Umbelliferae; Verlag von Wilhelm Engelmann: Leipizig, German, 1897; Volume 3, pp. 63-150.

16. Downie, S.R.; Katz-Downie, D.S.; Watson, M.F. A phylogeny of the flowering plant family Apiaceae based on chloroplast DNA rpl16 and rpoC1 intron sequences: Towards a suprageneric classification of subfamily Apioideae. Am. J. Bot. 2000, 87, 273-292. [CrossRef]

17. Joh, H.J.; Kim, N.-H.; Jayakodi, M.; Jang, W.; Park, J.Y.; Kim, Y.C.; In, J.-G.; Yang, T.-J. Authentication of golden-berry P. ginseng cultivar 'Gumpoong' from a landrace 'Hwangsook'based on pooling method using chloroplast-derived markers. Plant Breed Biotech. 2017, 5, 16-24. [CrossRef]

18. Nguyen, V.B.; Giang, V.N.L.; Waminal, N.E.; Park, H.-S.; Kim, N.-H.; Jang, W.; Lee, J.; Yang, T.-J. Comprehensive comparative analysis of chloroplast genomes from seven Panax species and development of an authentication system based on species-unique single nucleotide polymorphism markers. J. Ginseng Res. 2018. [CrossRef]

19. Palmer, J.D.; Thompson, W.F. Chloroplast DNA rearrangements are more frequent when a large inverted repeat sequence is lost. Cell 1982, 29, 537-550. [CrossRef]

20. Goulding, S.E.; Olmstead, R.G.; Morden, C.W.; Wolfe, K.H. Ebb and flow of the chloroplast inverted repeat. Mol. Gen. Genet. MGG 1996, 252, 195-206. [CrossRef] 
21. Dugas, D.V.; Hernandez, D.; Koenen, E.J.; Schwarz, E.; Straub, S.; Hughes, C.E.; Jansen, R.K.; Nageswara-Rao, M.; Staats, M.; Trujillo, J.T.; et al. Mimosoid legume plastome evolution: IR expansion, tandem repeat expansions, and accelerated rate of evolution in clpP. Sci. Rep. 2015, 5, 16958. [CrossRef]

22. Park, S.; An, B.; Park, S. Reconfiguration of the plastid genome in Lamprocapnos spectabilis: IR boundary shifting, inversion, and intraspecific variation. Sci. Rep. 2018, 8, 13568. [CrossRef]

23. Dong, W.; Liu, J.; Yu, J.; Wang, L.; Zhou, S. Highly variable chloroplast markers for evaluating plant phylogeny at low taxonomic levels and for DNA barcoding. PLoS ONE 2012, 7, e35071. [CrossRef]

24. Dong, W.; Xu, C.; Li, C.; Sun, J.; Zuo, Y.; Shi, S.; Cheng, T.; Guo, J.; Zhou, S. ycf1, the most promising plastid DNA barcode of land plants. Sci. Rep. 2015, 5, 8348. [CrossRef]

25. Chen, S.; Yao, H.; Han, J.; Liu, C.; Song, J.; Shi, L.; Zhu, Y.; Ma, X.; Gao, T.; Pang, X. Validation of the ITS2 region as a novel DNA barcode for identifying medicinal plant species. PLoS ONE 2010, 5, e8613. [CrossRef] [PubMed]

26. Kim, C.-K.; Seol, Y.-J.; Perumal, S.; Lee, J.; Waminal, N.E.; Jayakodi, M.; Lee, S.-C.; Jin, S.; Choi, B.-S.; Yu, Y. Re-exploration of U's Triangle Brassica Species Based on Chloroplast Genomes and 45S nrDNA Sequences. Sci. Rep. 2018, 8, 7353. [CrossRef] [PubMed]

27. Wolfe, K.H.; Li, W.H.; Sharp, P.M. Rates of nucleotide substitution vary greatly among plant mitochondrial, chloroplast, and nuclear DNAs. Proc. Natl. Acad. Sci. USA 1987, 84, 9054-9058. [CrossRef]

28. Plunkett, G.M.; Soltis, D.E.; Soltis, P.S. Evolutionary patterns in Apiaceae: Inferences based on matK sequence data. System. Bot. 1996, 477-495. [CrossRef]

29. Plunkett, G.M.; Soltis, D.E.; Soltis, P.S. Clarification of the relationship between Apiaceae and Araliaceae based on matK and rbcL sequence data. Am. J. Bot. 1997, 84, 565-580. [CrossRef]

30. Downie, S.R.; Ramanath, S.; Katz-Downie, D.S.; Llanas, E. Molecular systematics of Apiaceae subfamily Apioideae: Phylogenetic analyses of nuclear ribosomal DNA internal transcribed spacer and plastid rpoC1 intron sequences. Am. J. Bot. 1998, 85, 563-591. [CrossRef]

31. WANG, C.B.; MA, X.G.; HE, X.J. A taxonomic re-assessment in the Chinese Bupleurum (Apiaceae): Insights from morphology, nuclear ribosomal internal transcribed spacer, and chloroplast (trnH-psbA, matK) sequences. J. System. Evol. 2011, 49, 558-589. [CrossRef]

32. Feist, M.A.E.; Downie, S.R.; Magee, A.R.; Liu, M.R. Revised generic delimitations for Oxypolis and Ptilimnium (Apiaceae) based on leaf morphology, comparative fruit anatomy, and phylogenetic analysis of nuclear rDNA ITS and cpDNA trnQ-trnK intergenic spacer sequence data. Taxon 2012, 61, 402-418. [CrossRef]

33. Downie, S.R.; Katz-Downie, D.S. A molecular phylogeny of Apiaceae subfamily Apioideae: Evidence from nuclear ribosomal DNA internal transcribed spacer sequences. Am. J. Bot. 1996, 83, 234-251. [CrossRef]

34. Downie, S.R.; Spalik, K.; Katz-Downie, D.S.; Reduron, J.-P. Major clades within Apiaceae subfamily Apioideae as inferred by phylogenetic analysis of nrDNA ITS sequences. Plant Div. Evol. 2010, 128, 111-136. [CrossRef]

35. Liu, J.; Shi, L.; Han, J.; Li, G.; Lu, H.; Hou, J.; Zhou, X.; Meng, F.; Downie, S.R. Identification of species in the angiosperm family Apiaceae using DNA barcodes. Mol. Eco. Res. 2014, 14, 1231-1238. [CrossRef]

36. Allen, G.; Flores-Vergara, M.; Krasynanski, S.; Kumar, S.; Thompson, W. A modified protocol for rapid DNA isolation from plant tissues using cetyltrimethylammonium bromide. Nat. Protoc. 2006, 1, 2320. [CrossRef] [PubMed]

37. Lee, H.O.; Kim, K.; Lee, S.-C.; Lee, J.; Lee, J.; Kim, S.; Yang, T.-J. The complete chloroplast genome sequence of Ledebouriella seseloides (Hoffm.) H. Wolff. Mit. DNA Part A 2016, 27, 3498-3499. [CrossRef] [PubMed]

38. Lee, S.-C.; Oh Lee, H.; Kim, K.; Kim, S.; Yang, T.-J. The complete chloroplast genome sequence of the medicinal plant Glehnia littoralis F. Schmidt ex Miq.(Apiaceae). Mit. DNA Part A 2016, 27, 3674-3675. [CrossRef] [PubMed]

39. Ruhlman, T.; Lee, S.-B.; Jansen, R.K.; Hostetler, J.B.; Tallon, L.J.; Town, C.D.; Daniell, H. Complete plastid genome sequence of Daucus carota: Implications for biotechnology and phylogeny of angiosperms. BMC Genom. 2006, 7, 222. [CrossRef] [PubMed]

40. Kurtz, S.; Phillippy, A.; Delcher, A.L.; Smoot, M.; Shumway, M.; Antonescu, C.; Salzberg, S.L. Versatile and open software for comparing large genomes. Genome Biol. 2004, 5, R12. [CrossRef] [PubMed]

41. Wyman, S.K.; Jansen, R.K.; Boore, J.L. Automatic annotation of organellar genomes with DOGMA. Bioinformatics 2004, 20, 3252-3255. [CrossRef] 
42. Lohse, M.; Drechsel, O.; Bock, R. OrganellarGenomeDRAW (OGDRAW): A tool for the easy generation of high-quality custom graphical maps of plastid and mitochondrial genomes. Cur. Genet. 2007, 52, 267-274. [CrossRef] [PubMed]

43. Katoh, K.; Standley, D.M. MAFFT multiple sequence alignment software version 7: Improvements in performance and usability. Mol. Biol. Evol. 2013, 30, 772-780. [CrossRef] [PubMed]

44. Frazer, K.A.; Pachter, L.; Poliakov, A.; Rubin, E.M.; Dubchak, I. VISTA: Computational tools for comparative genomics. Nucl. Acids Res. 2004, 32, W273-W279. [CrossRef]

45. Brudno, M.; Malde, S.; Poliakov, A.; Do, C.B.; Couronne, O.; Dubchak, I.; Batzoglou, S. Glocal alignment: Finding rearrangements during alignment. Bioinformatics 2003, 19 (Suppl. 1), i54-i62. [CrossRef]

46. Schwartz, S.; Kent, W.J.; Smit, A.; Zhang, Z.; Baertsch, R.; Hardison, R.C.; Haussler, D.; Miller, W. Human-Mouse Alignments with BLASTZ. Genome Res. 2003, 13, 103-107. [CrossRef]

47. Yang, Z. PAML: A program package for phylogenetic analysis by maximum likelihood. Comput. Appl. Biosci. 1997, 13, 555-556. [CrossRef] [PubMed]

48. Bouckaert, R.; Heled, J.; Kühnert, D.; Vaughan, T.; Wu, C.-H.; Xie, D.; Suchard, M.A.; Rambaut, A.; Drummond, A.J. BEAST 2: A software platform for Bayesian evolutionary analysis. PLoS Comput. Biol. 2014, 10, e1003537. [CrossRef] [PubMed]

(C) 2019 by the authors. Licensee MDPI, Basel, Switzerland. This article is an open access article distributed under the terms and conditions of the Creative Commons Attribution (CC BY) license (http://creativecommons.org/licenses/by/4.0/). 